and M. Hue. The views on the alignments were varied; they were ex-votos, and they were connected with the Trojan war; but the majority hesitated to express an opinion. M. le Rouzic, Dr. Baudouin and others, subject to more extensive researches in Brittany and elsewhere, were disposed to connect them with a solar cult. Among other papers, Dr. Atgier discussed the Megalithic enclosures, and $M$. de Clérambant galgals, or cairns, in Indre-et-Loirc.

M. de Villemereuil proposed a motion on the State protection of megaliths. Speaking generally, it may be said that both the discussions and the numerous papers were of much interest, and the meetings were attended by more than a hundred members.

The following three days were taken up with excellently organised excursions; weather, vehicles, meals, and speeches, all were of the best, and more than a hundred took part in each excursion. The first day was consecrated to the Gulf of Morbihan, and among the objects visited were the cromlechs of Kergonan, the tumulus of Gavr'inis, and the magnificent dolmens of Locmariaquer, including the largest known menhir. On the second day visits were paid to the little-known alignments of St. Pierre, in Quiberon, and of Erdeven, and to the dolmens of Roch-enAud, Crocuno, Rondossec, \&c.

The third day was reserved for Carnac and its marvellous alignments Menec, Kermario, and Kerlescant.

Worthy of special mention were the visits to the tumulus of Moustoir-Carnac, and to the Miln Museum, where the secretary of the congress paid a well-deserved tribute to the brilliant efforts of the regretted founder and his enthusiastic and devoted pupil, M. le Rouzic. Finally, a visit was rendered to the splendid tumulus of St. MichelCarnac, so well cared for by M. d'Ault du Mesnil, president of the Megalithic Monuments Commission, who himself acted as guide.

In the course of the three days numerous speeches were made by foreign members, who were roused to enthusiasm alike by the monuments and by the organisation of the gathering. Mention must be made of the utterances of M. Rutot, on the Gulf of Morbihan; of Dr. Baudouin, on submerged megaliths in Brittany and Vendée, and on the technique of restorations; and of the erudition of $\mathrm{M}$. de Mortillet, as well as of the demonstrations of MM. d'Ault du Mesnil and le Rouzic; the latter also spolke in the Miln Museum on the alignments of Carnac, and on his researches on the spot.

As the scene of the next congress in 1907 Abbeville was suggested by more than one speaker. Before the congress separated, the healths of M. de Mortillet, Dr. Baudouin, and M. Giraux were proposed in eulogistic terms. As M. Rutot said, a society that has been able to accomplish so much in its infancy will do much more in its maturer years, and this was equally the opinion of the foreign savants who attended the meeting.

\section{A NEW SPECIMEN OF THE OKAPI.}

IN a letter from the Congo Free State, published in the

Times of September 26, Major P. H. G. Powell-Cotton states that he has succeeded in obtaining the skeleton and skin of a fine male okapi. This animal was killed at Makala, in the Ituri forest, by the native hunter Agukki, who shot the two specimens taken to Europe by Dr. David. After careful inquiry, Major Powell-Cotton is unable to satisfy himself that any European has hitherto killed an okapi. A Swiss official named Jeannet, in the employ of the Congo Government, was, however, in 1905 shown one of these animals by a native as it stood in thick covert, where it was shot by the latter. This the writer belicves to be the first living okapi (or " kangi," as it is called by the Makala natives) seen by a European.

According to information furnished by the Mambutt (pigmies), the okapi is generally a solitary animal, the two members of a pair invariably feeding apart, although, together with their single calf, they may frequent the same section of the forest. The calf, which is born in May, is left hidden in covert by the female, who returns to it at intervals for feeding purposes. Hearing and smell are very acute in the okapi, so that the sound of an axe or the faintest scent of man drives it from its feeding grounds into the depths of the forest. Even when feeding it is restless, and it seldom reposes long in the same lair. In the Ituri forest these animals avoid swampy ground, and always drink from clear running streams. During rain they seek shelter in the densest thickets or even under an abandoned roof, and it is at such times that they are most usually seen by the natives.

In the Ituri forest the okapi does not eat the giant leaves of Sarcophrynium arnoldianum, which Major Powell-Cotton believes to be the plant alluded to by Captain Boyd-Alexander in his account of the animal in the Welle district. Specimens of four different kinds of leaves which form the food of the Ituri forest okapi are being brought home for identification.

\section{UNIVERSITY AND EDUCATIONAL INTELLIGENCE.}

ThE honorary degree. of LL.D. has been conferred upon Sir Thomas Barlow and Prof. C. S. Sherrington, F.R.S., by Harvard University.

At a Convocation of the University of Durham, held on September 29, the honorary degree of D.Sc. was conferred upon Sir William White, K.C.B., and Prof. Lebour.

Prof. Wien, who occupies the chair of physics at Würzburg, informs us that he has declined the invitation to succeed the late Prof. Drude as professor of physics in the University of Berlin, because the Prussian Government is unable to undertake the erection of a modern physical laboratory there.

Prof. E. A. Minchin, F.R.S., the recently appointed professor of protozoology in the University of London, will deliver his inaugural lecture on "The Scope and Problems of Protozoology" on November 15. The University library, in which is included the Goldsmiths' Company's library of economic literature, will be opened by the Chancellor on the afternoon of Friday, October 26.

THE new calendar of University College, London, contains an interesting outline of the history of the college by Dr. G. Carey Foster, F.R.S. The contribution deals with the growth and development of the University of London as a teaching university, and the part played by University College in that development. Particulars are given of the post-graduate courses offered this session in all faculties, and of the original work produced in the college during last session. The number of research and post-graduate students last year was 134 , as against II9 in the previous session.

THE first volume of the report for 1904 of the Commissioner of the United States Bureau of Education has at last been issued. A gratifying feature noted in the reports of the agricultural and mechanical colleges is the largely increased aid granted them by the several States and Territories. This aid amounted for the year to about I, I3I,00ol., an increase of more than 200,oool. over the amount for the preceding year. A chapter of more than a hundred pages is devoted to the regulations relating to pensions and insurance in all German universities. The data were coiliected by Prof. Julius Hatscheck, of Heidelberg, for Dr. Theodore Marburg, trustee of Johns Hopkins University, and by the latter presented to the U.S. Commissioner of Education. It appears that in Germany membership in any teaching body means, nolens volens, the payment of regular contributions to the pension fund of that. body, except in elementary schools, where the State assumes the entire burden of pension payment. Dr. John W. Hoyt contributes a detailed account of the University of Paris during the Middle Ages. Among other chapters of interest in the report, which runs to 1176 pages, may be mentioned two on education at the St. Louis Exposition and one on higher education in England as affected by the Act of 1902 , in which prominence is given to Prof. Sadler's reports to various county councils.

At the University of Leeds on Monday, the inaugural address of the new session was delivered by Sir James Crichton-Browne upon the subject of "Universities and Medical Education." In the course of his remarks, he 
said that centuries ago gifts were given for the promotion of objects equivalent to those which modern universities hold in view, which, considering the pecuniary resources of those who gave them, should put our most open-handed modern millionaires to shame. England has been remiss of late in perceiving and promoting those interests that hinge on scientific and medical research. In this direction Germany has stolen a march upon us, for the various Governments in that Empire have unstintedly provided their universities with fully-equipped research laboratories, organised and conducted by professorial directors. A university is something more than a medical school, a workshop of research, or a home of science. It must have loftier aims than material advancement or commercial prosperity. It must provide for culture in its widest sense, afford intellectual guidance, encourage individuality, take cognisance of the theoretical problems that arise in the progress of civilisation, be a storehouse of knowledge, and a gymnasium for the exercise of all the powers of the mind; and to be truly a university it must be an organism, and not a mere conglomeration of parts. The one great objection to the multiplication of universities is that they may tend to become local seminaries, somewhat parochial in spirit, and fed exclusively from one district, for it would be a misfortune to a boy to pass from a secondary school to a university in the next street, where he would meet as his fellow-students only his old schoolfellows, and where, however amply fed with knowledge, he would still be surrounded by the same traditions and associations and shop amongst which he had been brought up. A provincial university is a contradiction in terms. What is wanted is a group of territorial universities, each with distinctive features of its own, specially adapting it to its environment, but all affording the most liberal instruction, the finest culture, the best intellectual discipline of the day, and collectively meeting the higher educational needs of the whole country.

\section{SOCIETIES AND ACADEMIES. LONDON.}

Royal Society, June 2r.- "Regeneration of Nerves." By Dr. F. W. Mott, F.R.S., Prof. W. D. Halliburton, F.R.S., and Arthur Edmunds.

Five sets of experiments are recorded as a contribution to the discussion as to whether the regeneration of nervefibres is autogenetic or not. The experimental methods approach the subject in different ways, and in no case was any evidence forthcoming of auto-regeneration.

The facts recorded, taken in conjunction with those published by such observers as Cajal and Langley and Anderson, form, on the other hand, strong pieces of evidence in favour of the Wallerian doctrine that new nerve-fibres are growths from the central ends of divided nerve trunks. The experimental facts recorded by those who, like Bethe and Kennedy, hold the opposite view, are susceptible of easy explanation, mainly on the lines emphasised by Langley and Anderson, of accidental and unnoticed connection of the peripheral segments with the central nervous system by means of other nerves cut through in the operation. If such connection is effectually prevented, real regeneration of structure and restoration of function never occur.

Moreover, the regenerated fibres always degenerate in a peripheral direction, and in a peripheral direction only, when the link that binds them to the central nervous system is again severed. Perhaps the most striking of the facts brought out in the present paper is in reference to the development of the medullary sheath; this appendage of the axis cylinder appears earliest at situations near the point where the ends of a nerve have been joined together, and reaches the distal portions later.

What takes place in the peripheral segment of a divided nerve is a multiplication, elongation, and union into long chains of the neurilemmal cells. The same change is even more vigorous at the central termination of the cut nerve; and the view of the phagocytic and nutritive function attributed to this sheath has been supported independently by some striking observations of Graham Kerr which are referred to. At the central end this nutritive function is effective, and frovides for the nourishment of the actively lengthening axis cylinders. At the peripheral end, unless the axons reach it, it is ineffective in so far as any real new formation of nerve-fibres is concerned. If, however, the axons reach the peripheral segment, the work of the neurilemmal cells has not been useless, for they provide the supporting and nutritive elements necessary for their continued and successful growth. The neurilemmal activity appears to be essential, for without it, as in the central nervous system, regeneration does not take place.

According to Graham Kerr, the formation of neurofibrillæ may possibly take place in the protoplasmic residue of the degenerated axis cylinder; according to Marinesco, this property is assigned to the neurilemmal elements themselves, a proposition which is extremely improbable, seeing that these elements are mesoblastic. In either case these two observers consider that the neuro-fibrilla, however formed, are ineffective until they are activated by union with those of the central axons. The present observations do not entirely exclude this view, but, on the other hand, they lend it no support. The facts are readily explicable, however, on the theory that the nerve-fibres are growths from the central ends of divided nerves.

"The Ionisation produced by Hot Platinum in Different Gases." By Prof. O. W. Richardson. Communicated by Prof. J. J. Thomson, F.R.S.

The present paper forms an account of an experimental investigation of the steady positive ionisation produced by hot bodies, platinum being assumed to be typical.

The following are the chief results:-

The positive ionisation, i.e. the number of positive ions produced by I sq. cm. of platinum surface per second, possesses a minimum value, which depends on temperature and pressure, in most gases. The positive ionisation in oxygen at a low pressure (less than I mm.) is much greater than in the other gases tried. In oxygen at low pressures, and temperatures below $1000^{\circ} \mathrm{C}$., the ionisation varies as the square root of the pressure; at higher temperatures and low pressures it varies nearly directly as the pressure; whilst at higher pressures at all temperatures the variation with pressure is slower, so that at pressures approaching atmospheric the ionisation becomes practically independent of the pressure.

The variation with pressure in air is similar to that in oxygen. In nitrogen and hydrogen the ionisation appeared to increase more rapidly with the pressure at high pressures than in oxygen. In very pure helium at low pressures there was a positive ionisation which was a function of the pressure.

The experiments on ionisation by collisions indicate that the positive ions liberated by hot platinum in oxygen are of the same order of magnitude as those set free by the collisions.

The positive leak in oxygen always oscillated around a certain value under specified conditions. It was, therefore, never steady, so the minimum values were taken. This variability was much less marked in the other gases.

The minimum value of the positive ionisation was found to remain practically constant with a wire heated during three months at various times (for 150 hours altogether) in oxygen at $900^{\circ}-1000^{\circ} \mathrm{C}$. Moreover, four different wires of different dimensions after continued heating in oxygen gave nearly the same value for the ionisation at the same temperatures and pressures.

The positive ionisation in air at constant temperature is smaller than that which would be obtained if the nitrogen were withdrawn, so as to leave only oxygen at a low pressure. The nitrogen, therefore, exerts an inhibiting effect on the oxygen.

The minimum value of the positive ionisation at a definite pressure in all gases appears to be connected with the temperature by the relation first deduced by the author for the negative ionisation. This relation may be written $i=\mathrm{A} \theta^{\frac{\pi}{2}} e^{-\mathrm{Q} / 2 \theta}$, where $i$ is the ionisation, $\theta$ is the absolute temperature, and $\mathrm{A}$ and $\mathrm{Q}$ are constants. The value of the constant $Q$, which is a measure of the energy associated with the liberation of an ion, is in most cases smaller for the positive than for the negative ionisation.

These results refer to wires which have been heated in

NO. 1927 , VOL. 747 